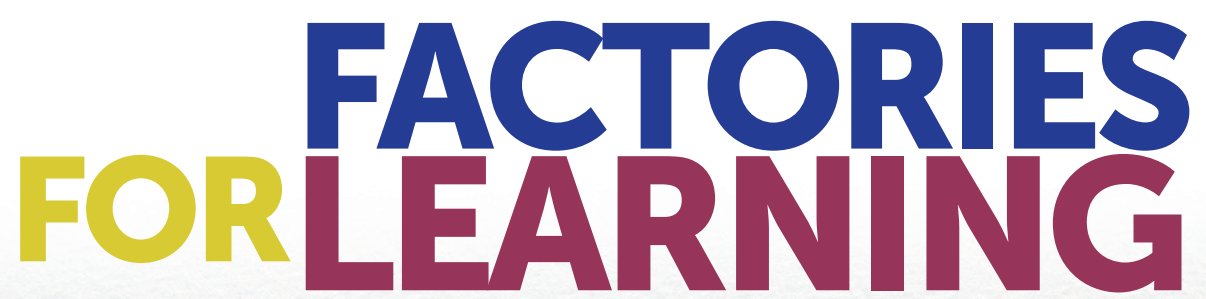

MAKING RACE, CLASS AND INEQUALITY IN THE NEOLIBERAL ACADEMY

\title{
Christy Kulz
}
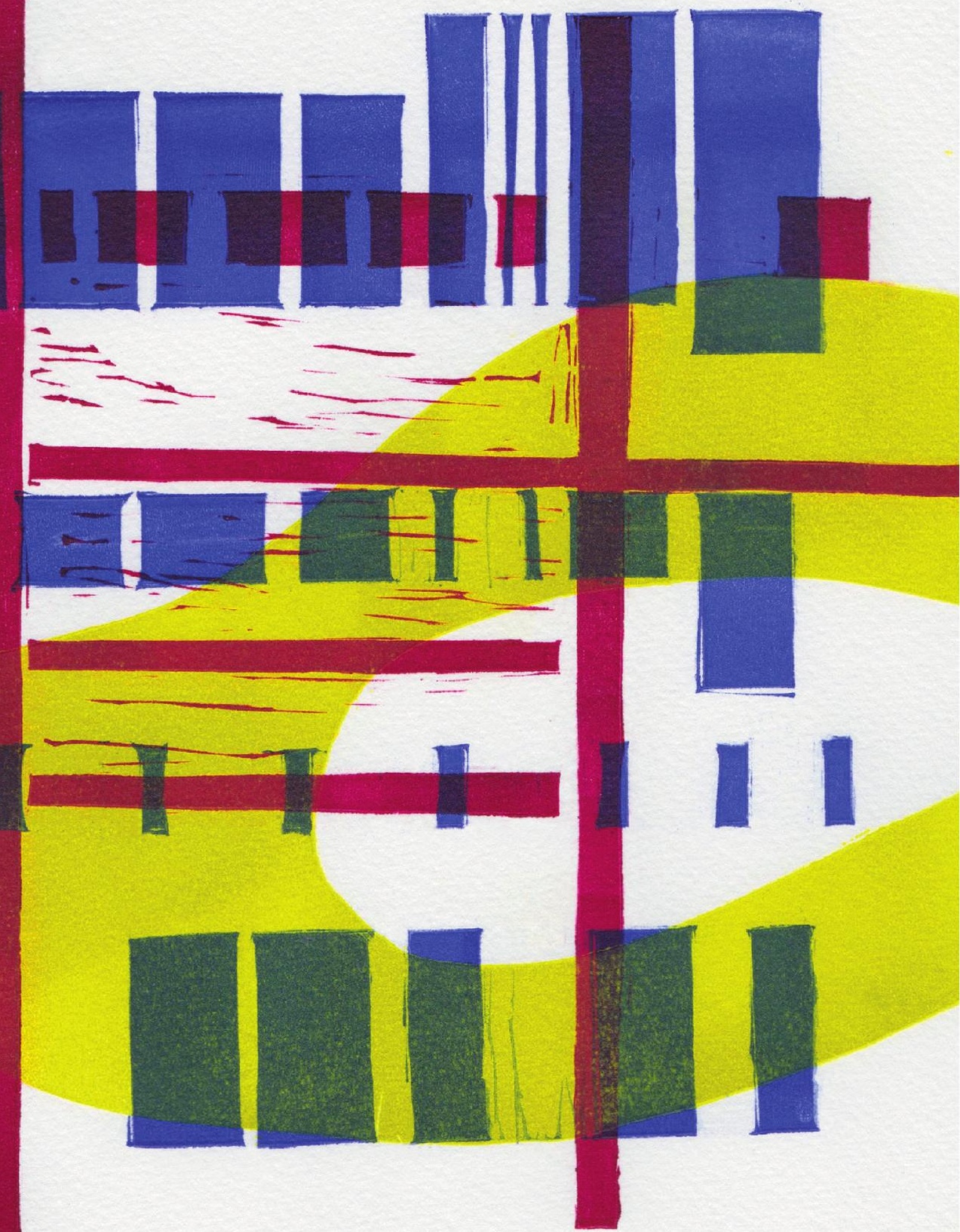

Foreword by Herdi Safia Hiliza 


\section{Factories for learning}

\section{MANCHESTER 1824}

Manchester University Press 


\section{Praise for Factories for learning}

Kulz's brilliant and chilling ethnography of Dreamfields Academy shows that students no longer merely learn to labour, as Paul Willis once put it, but rather education itself becomes a factory. Schools do not foster critical intelligence but rather make, shape and discipline young people in the doctrine and dream world of neoliberal capitalism. The book reveals the cruel hopes and authoritarian aspects of a modern urban academy schooling. It left me with a sense of outrage because these black, white and Asian working-class students, and every student for that matter, deserve so much more from education than this. This book outlines with sociological precision and keen attentiveness the shape of that educational betrayal.

Professor Les Back, Goldsmiths, University of London

This book is a 'must read' for all, particularly for teachers and parents. Christy Kulz's ethnographic study unmasks how education practice within an urban academy school is raced, classed and gendered. This timely and exceptional book reveals how inequity is sedimented within the academies policy. It reveals a complex picture of how this academy is led and managed; how the relentless pursuit of better outcomes drives the ambitious aspirations of the headteacher and how the ethos of 'structure liberates' reflects the zealous drive to educate and civilise 'urban' children to become units of economic productivity to attain social mobility. The headteacher's evangelistic zeal is realised through disciplinary and regimented processes which subjugate teachers and pupils.

Christy Kulz shows how inequality is perpetuated in the school through the panoptic architecture of the school buildings, the stark surveillance of pupils and the enforcement of draconian rules which re-inscribe gender, race and class stereotypes within a regimen that serves to 'normalise' or whiten pupils' identities. She shows how this results in symbolic violence on black and minority ethnic bodies and how, for some pupils, the promise of social mobility remained an unrealised aspiration given the insurmountable structural inequalities they encountered every day.

This book will be a seminal text documenting the effects of the academies policy on schools, teachers and a generation of young people.

Professor Vini Lander, Edge Hill University

Christy Kulz has produced an incendiary and detailed account of the reality of life in an academy school. Kulz's ethnographic research, using a single school case study to explore wider issues of education reform, control and the creation of inequity, is in the best traditions of British sociology of education. The book is essential reading for anyone interested in the grim reality of education on the conveyor belt that lies behind the shiny deceitful rhetoric of aspirations and social mobility.

Professor David Gillborn, University of Birmingham 


\title{
Factories for learning
}

Making race, class and inequality in the neoliberal academy

\author{
Christy Kulz
}

\section{Ethnographies}

Series editor

Alexander Thomas T. Smith

Manchester University Press 
Copyright (C) Christy Kulz 2017

The right of Christy Kulz to be identified as the author of this work has been asserted by her in accordance with the Copyright, Designs and Patents Act 1988.

Published by Manchester University Press

Altrincham Street, Manchester M1 7JA

www.manchesteruniversitypress.co.uk

British Library Cataloguing-in-Publication Data

A catalogue record for this book is available from the British Library

ISBN 9781526116178 hardback

ISBN 9781526116192 paperback

First published 2017

The publisher has no responsibility for the persistence or accuracy of URLs for any external or third-party internet websites referred to in this book, and does not guarantee that any content on such websites is, or will remain, accurate or appropriate.

Typeset in Minion by

Servis Filmsetting Ltd, Stockport, Cheshire 